\title{
Effects of packaging methods on shelf life of ratite meats
}

\author{
Olaf K. Horbańczuk, Agnieszka Wierzbicka \\ Faculty of Human Nutrition and Consumer Sciences, \\ Warsaw University of Life Sciences, 02-776 Warsaw, Poland \\ olsonhorb@gmail.com
}

Received: April 21, 2017

Accepted: August 8, 2017

\begin{abstract}
Over the last years a growing demand for ratite meat, including ostrich, emu, and rhea has been observed in the world. Ratite meat is recognised as a dietetic product because of low level of fat, high share of PUFA, favourable n6/n3 ratio, and higher amounts of iron content in comparison with beef and chicken meat. The abundance of bioactive compounds, e.g. PUFA, makes ratite meat highly susceptible to oxidation processes. Moreover, $\mathrm{pH}$ over 6 creates favourable environment for fast microbial growth during storage conditions affecting its shelf life. However, availability of information on ratite meat shelf life among consumers and industry is still limited. Thus, the aim of the present review is to provide current information about the effect of ratite meat packaging type, i.e. air packaging, vacuum packaging with skin pack, modified atmosphere packaging (MAP), on its shelf life quality during storage, including technological and nutritional properties.
\end{abstract}

Keywords: meat, ratite, packaging type, shelf life, quality.

\section{Introduction}

Over the last years a growing demand for ratite meat, including ostrich, emu, and rhea has been observed in the world $(12,13,22,24,35,38,39,42)$. The global market of ratite meats is gaining popularity due to health-conscious consumers, who are becoming increasingly careful in choosing lean alternatives over traditional red meats (31). One of the reasons for such interest is that ratite meat is recognised as a valuable dietetic meat mainly because of its low level of fat, high share of polyunsaturated fatty acids (PUFAs) $(10,36)$, favourable $\mathrm{n} 6 / \mathrm{n} 3$ ratio, and significantly higher amount iron (haeme form) in comparison with beef and chicken meat. Moreover, ratite meat is rich in group B vitamin, selenium, copper, and biologically active peptides, such as carnosine (emu) and anserine (ostrich). The abundance of bioactive compounds (PUFA or ironcontaining compounds) makes ratite meat highly susceptible to oxidation processes. It should be noted that the oxidative deterioration of the PUFAs causes formation of hydroperoxides, and finally leads to formation of short-chain aldehydes, ketones, and other oxygenated compounds, which are considered to be responsible for the development of rancidity in stored food. Oxidation in meat is also closely related to the breakdown of haeme-iron and release of iron from the porphyrin ring (14). Lipid oxidation accelerates in the immediate post-slaughter period and during handling, processing, storage, and cooking, producing discolouration, drip losses, off-odour, off-flavour, and texture defects (40). Lipid oxidation is an important factor regarding shelf life and consumer acceptance of fresh meat. Dark visual appearance of ostrich meat can affect consumer preferences. The meat maturation is also followed by the second phase, where proteins are degraded, with the accumulation of low-molecular nitrogenous compounds and a slight rise in $\mathrm{pH}$ (26). Thus, protein oxidation is responsible for many biological modifications, such as protein fragmentation or aggregation, decreased protein solubility, and decreased amino acid bioavailability (43). Active oxygen species attack the side chain of basic amino acids and can convert them into carbonyl derivatives.

Moreover, ratite meat is characterised by high $\mathrm{pH}$ (over 6), which creates a favourable environment for fast microbial spoilage under packaging conditions (2). Poławska et al. (37) concluded that poor microbial 
quality and high $\mathrm{pH}$ of ostrich meat post-slaughter could be responsible for high microbial loads during storage. High final $\mathrm{pH}$ causes dark colour, high water-holding capacity, and limited shelf life of meat, and is normally associated with pre-slaughter stress. Thus, such factors as $\mathrm{pH}$, which has been considered as one of the main parameters in the microbiological quality of the meat, together with the initial bacterial contamination, temperature of the meat during storage, as well as type of packaging, all play a major role in the final quality of the meat (9).

As mentioned above, on the one hand ratite meat is a high-quality dietetic product, but on the other it is very sensitive to deterioration during storage. Moreover, the consumption of ratite meat, especially ostrich meat, is increasing in the world, and therefore improving the extent of its shelf life and protection of the bioactive compounds as well as technological and food safety aspects are crucial for potential consumers and for further development of this new meat industry. However, the knowledge regarding these issues compared to beef or chicken meat is still limited. Thus, the aim of the review is to provide scientific knowledge about the influence that the type of packaging has on ratite meat shelf life quality, including technological and nutritional properties.

\section{Type of packaging and ratite meat shelf life quality}

Ratite carcasses are typically chilled for $24-48 \mathrm{~h}$ post-mortem, cut, and immediately packed before marketing (40). Different types of packaging of ratite meat are currently available on the market: traditional air packaging (AP), vacuum-packaging (VP) including vacuum skin pack (VSP), and modified atmosphere packaging (MAP). VP offers anaerobic conditions inside the package, which leads to further shelf life extension and provides stable colour. VSP is an advanced type of VP which helps to avoid the formation of film wrinkles by making upper film shrink tightly around meat. MAP is a useful technique to maintain the sensory quality and to extend the shelf life of meat $(1,11)$. The principle of MAP is the replacement of the atmosphere surrounding a product before sealing; carbon dioxide, oxygen, and nitrogen are the most commonly used gases.

\section{Air-packaging and vacuum packaging including skin pack}

One of the first publications regarding the impact of the type of packaging on ratite meat shelf quality was reported by Otremba et al. (34). They worked on previously frozen (at $-40^{\circ} \mathrm{C}$ for five days) ostrich meat (steaks and ground meat vacuum-packaged) which was then placed for 28 days into a $0^{\circ} \mathrm{C}$ walk-in cooler and its shelf life was evaluated. The authors demonstrated that the meat had aerobic plate counts of less than $6 \mathrm{log}$ $\mathrm{CFU} / \mathrm{g}$ during a refrigerated storage for 14 days. Aroma was also acceptable after 14 days. After this period the aroma and colour were less acceptable and more than $50 \%$ of the surface of ostrich meat turned brown (Table 1). The authors suggested that previously frozen, vacuumpackaged ostrich meat, stored under refrigerated conditions, should be used within 10 days.

Shelf life quality of ostrich meat steak air- and vacuum-packed and stored at different temperatures $\left(4^{\circ} \mathrm{C}\right.$ and $\left.10^{\circ} \mathrm{C}\right)$ was investigated by Gonzalez-Montalvo et al. (19). They reported that $\mathrm{pH}$ was higher in AP in comparison with VP after six days of observations. In their study, VP ostrich meat showed lower microbial count as compared to AP at $10^{\circ} \mathrm{C}$ for Listeria monocytogenes and at $4^{\circ} \mathrm{C}$ and $10^{\circ} \mathrm{C}$ for Escherichia coli. Storage temperature influenced the bacteria count during the time of storage, especially in AP. General acceptability of this meat for consumption was 6 days for AP, and 9-12 days for VP stored at $10^{\circ} \mathrm{C}$ and $4{ }^{\circ} \mathrm{C}$, respectively. Similar results were demonstrated by Balamatsia et al. (3) who stored chicken breast fillets at $4^{\circ} \mathrm{C}$ under AP and VP conditions; although VP was most effective in reducing the growth of aerobic bacteria, the shelf life of fresh chicken meat was 6-7 and 9-10 days, respectively. Capita et al. (9) stored ostrich meat at similar temperatures under AP and VP and stated that for most microbial groups temperature significantly influenced bacterial levels up to day 6 of storage, while gas atmosphere had a significant effect on days 6 and 9 . VP ostrich meat stored at $4^{\circ} \mathrm{C}$ demonstrated the lowest microbial loads on day 9. Ntzimani et al. (33) found inhibition of microbial growth, including Pseudomonas spp., on turkey fillets stored under AP, VP, and VSP at $4^{\circ} \mathrm{C}$. According to them, VSP is the most effective, followed by VP. The results of the study by Brenesselova et al. (7) showed that the shelf life of ostrich meat stored at $2{ }^{\circ} \mathrm{C}$ was affected by different packaging conditions (vacuum against the normal atmosphere). The storage of ostrich meat in VP had a positive effect on the biochemical, microbiological, and sensory parameters compared to non-vacuum packed meat. In VP samples not only was the oxidation process reduced, but the microbial spoilage as well. The microbial levels of refrigerated VP ostrich steaks were also assessed by Alonso-Calleja et al. (2), who investigated meat samples purchased in retail outlets in Spain within three to seven days after storage. They showed that the samples with $\mathrm{pH}$ higher than 5.8 had the highest $(\mathrm{P}>0.05)$ counts of most of the microbial groups, and the samples with $\mathrm{pH}$ lower than 5.8 had the lowest level. Vázquez et al. (46) studied beef under VP and VPS stored at $4^{\circ} \mathrm{C}$ and demonstrated a decrease in $\mathrm{pH}$ under both packaging methods. Moreover, microbiological quality after VSP proved to be superior with aerobic mesophiles and aerobes showing a slower growth.

In turn, vacuum-packed hot- and cold-deboned ostrich meat was stored for 21 days at $4{ }^{\circ} \mathrm{C}$ in the study by Botha et al. (5), who focused on the influence of hotdeboning on the quality of ostrich meat during refrigerated storage. Muscle $\mathrm{pH}$ did not differ $(\mathrm{P}>0.05)$ 
between hot- and cold-deboned muscles during storage. Hot-deboned muscles were tougher than cold-deboned muscles from $24 \mathrm{~h}$ up to 5 days. Moreover, hot-deboning caused more purge in the VP of the hot-deboned $(1.8 \%)$ than in the cold-deboned muscles $(0.7 \%)$ during the 21 -day aging period. In the case of beef, Lagerstedt et al. (27), who compared three types of meat packaging: VP, VSP, and MAP $\left(80 \% \quad \mathrm{O}_{2} / 20 \% \quad \mathrm{CO}_{2}\right)$, reported that VSP samples demonstrated the lowest amount of purge loss during storage, while VP samples had the highest one.

In the study by Seydim et al. (45), fresh ground ostrich meat was packaged under high oxygen $\left(\mathrm{O}_{2}\right)$, high nitrogen $\left(\mathrm{N}_{2}\right)$, vacuum (VA), and ambient air (AIR) atmospheres, and stored at $4^{\circ} \mathrm{C}$ for nine days. Initial $\mathrm{pH}$ of the meat was 6.1 and it declined slightly during storage. TBA values and hexanal content were the highest in $\mathrm{O}_{2}$ and the lowest in VA and $\mathrm{N}_{2}$ atmospheres. All packaging methods had generally similar effects on microbial outgrowth. Ground ostrich meat was below saleable quality in less than six days based on all of the meat attributes. For $\mathrm{O}_{2}$ packaging, however, quality based on lipid oxidation and colour properties indicated a shelf life of less than three days. According to the authors, oxidation is likely the limiting factor for shelf life of ground ostrich meat (45). However, in order to decrease the rate of oxidation in chicken meat, Keokamnerd et al. (25) supplied commercial rosemary oleoresin preparations to ground thigh meat under $80 \%$ $\mathrm{O}_{2} / 20 \% \mathrm{CO}_{2}$, achieving a positive effect on raw meat appearance during storage. Oxidation was slowed in meat with rosemary as indicated by lower TBA values, lower hexanal concentrations, and sensory scores.

Interesting research regarding quality characteristics and storage stability of three types of burgers prepared with ostrich meat (alone or mixed with pork or beef meat) were evaluated by Fernandez-Lopez et al. (15). Burgers consisting of ostrich and pork meat had a faster oxidation rate and became more oxidised than the others. Regarding their shelf life, all types of burgers had an unacceptable microbial load at the end of the storage time, which is a sign of spoilage. The authors concluded that further studies should assess the use of preservatives and antioxidants in order to enhance the presentation of burgers. Such study on increasing the antioxidant capacity of rosemary extract on minced chicken breast meat showed that active packaging is capable of delaying the lipid oxidation generated by the application of high pressure, and thus extends the shelf life of the meat (6).

Poławska et al. (37) evaluated the physical traits and fatty acids profile of ostrich meat enriched in n-3 fatty acids affected by type of packaging (VA vs. skinpackaging - VSP) in relation to refrigerated storage (for 14 days). During storage time, drip loss after seven days was significantly higher $(\mathrm{P}<0.001)$ in VA when compared to VSP samples. A significant decrease in the content of PUFA after 7 and 14 days of storage was also observed in VA packed meat compared to fresh meat, whereas no differences in the PUFA concentration were shown when VSP was used.
Another study evaluated the influence of frozen storage $\left(-20^{\circ} \mathrm{C}\right)$ for 120 days on the fatty acid composition of ostrich VP meat enriched with linseed and rapeseed (36). A decrease was noted in the PUFA content in the meat as related to frozen storage duration. The results suggest that freezing $\left(-20^{\circ} \mathrm{C}\right)$ is an acceptable method of preservation for ostrich meat enriched with n-3 fatty acids for up to 60 days. However, the changes in PUFA profile in the second period of storage (61-120 days) indicate that further research should be conducted to evaluate a prolonged frozen storage for 180 days or longer.

In the case of emu meat, the first available literature was supplied by Naveena et al. (32), who studied the effect of aging on the quality of emu meat under AP and VP conditions at $4{ }^{\circ} \mathrm{C}$ for 9 and 15 days. Microbial counts of emu meat (total plate and Enterobacteriaceae) remained higher in the AP in relation to the VP. The microbial load observed in emu meat remained below the threshold level of 7-8 $\log \mathrm{cfu} / \mathrm{g}$. Emu meat packed under AP condition also showed a significantly higher oxidation rate (TBARS - $1.2 \mathrm{mg} \mathrm{MDA} / \mathrm{kg}$ in comparison to VP - $0.1 \mathrm{mg} \mathrm{MDA} / \mathrm{kg}$ ). The authors demonstrated that the quality characteristics, especially tenderness of emu meat, can be improved through postmortem aging: six and nine days of storage under AP and VP conditions, at $4{ }^{\circ} \mathrm{C}$. On the other hand, Łopacka et al. (29) showed that storage of beef for up to 12 days is not sufficient to impact its tenderness, regardless of the packaging type: VSP, MAP, and their combination with semi-permeable inner VSP film (VSP-MAP). TBARS values obtained for steaks packaged in VSPMAP system were similar to those obtained in VSP and significantly lower than in MAP samples.

In the case of rhea meat there are only a few reports available in the current literature. The shelf life of rhea meat during storage under AP ( 5 days) at $4^{\circ} \mathrm{C}$ and VP (28 days) was investigated by Filgueras et al. (16), who also determined the influence of the muscle type: gastrocnemius (GN) and iliofiburalis (IF) on the rate of oxidation processes. Although the ultimate $\mathrm{pH}$ was similar in both muscles, the IF muscle presented higher lipid content and lower PUFA/SFA ratio than GN muscle. With storage under AP, lipid oxidation of rhea muscles increased up to $275 \%$ (Table 1). This increase was more rapid and marked in IF muscle. IF muscle presented higher oxidation processes and instability than GN muscle, altering its quality attributes. It can be partly explained by the fatty acid composition and the higher myoglobin content in IF than in GN muscle. The authors suggested that rhea meat industry should prioritise the adoption of VP storage instead of AP. In turn, Filgueras et al. (17) investigated the influence of frozen storage duration (at $-20^{\circ} \mathrm{C}$ and $-80^{\circ} \mathrm{C}$ ) until 180 days and cooking of rhea vacuum packed meat on its physical and oxidative changes. Generally in rhea meat, muscle type had no effect on physical parameters during frozen storage. However, the M. iliofiburalis was more susceptible to oxidation than the $M$. gastrocnemius. 
Table 1. The effect of chosen types of packaging and storage temperature on shelf life of ratite meats

\begin{tabular}{|c|c|c|c|c|c|}
\hline Meat type & $\begin{array}{l}\text { Type of } \\
\text { packaging }\end{array}$ & Storage temperature & $\begin{array}{l}\text { Storage } \\
\text { time } \\
\text { days (d) }\end{array}$ & Quality meat evaluation & Reference \\
\hline Ostrich & $\mathrm{VP}$ & $\begin{array}{l}\text { frozen in }-40^{\circ} \mathrm{C} \text { for } \\
5 \text { days, later stored } \\
\text { up to } 28 \mathrm{~d} \text { at } 0^{\circ}\end{array}$ & up to $28 \mathrm{~d}$ & $\begin{array}{l}\text { Aerobic plate counts of less than } 6 \log \text { CFU/g during a } \\
\text { refrigerated shelf life of } 14 \text { days. Aroma was acceptable at } 14 \\
\text { days. }\end{array}$ & (34) \\
\hline Ostrich & $\mathrm{VP}$ and $\mathrm{AP}$ & $4^{\circ} \mathrm{C}$ and $10^{\circ} \mathrm{C}$ & $6-12 d$ & $\begin{array}{l}\text { VP -lower microbial count as compared to AP at } 10^{\circ} \mathrm{C} \text { for } \\
\text { Listeria monocytogenes and at } 4^{\circ} \text { and } 10^{\circ} \mathrm{C} \text { for Escherichia coli. } \\
\text { Storage temperature influenced the bacteria count during time } \\
\text { of storage, especially in AP. }\end{array}$ & (19) \\
\hline Ostrich & VP and VPS & $4^{\circ} \mathrm{C}$ & $3-7 d$ & $\begin{array}{l}\text { Meat with } \mathrm{pH} \text { higher than } 5.8 \text { had the highest }(\mathrm{P}>0.05) \text { counts } \\
\text { for most of microbial groups, these with } \mathrm{pH} \text { lower than } 5.8 \text { had } \\
\text { the lowest level. }\end{array}$ & (2) \\
\hline $\begin{array}{l}\text { Fresh ground } \\
\text { ostrich }\end{array}$ & VP and AIR & $4^{\circ} \mathrm{C}$ & up to $9 \mathrm{~d}$ & $\begin{array}{l}\text { Initial } \mathrm{pH} \text { was } 6.1 \text { declined slightly during storage. TBA values } \\
\text { and hexanal content were lowest in VP. }\end{array}$ & $(45)$ \\
\hline $\begin{array}{l}\text { Hot- and cold- } \\
\text { deboned ostrich } \\
\text { meat }\end{array}$ & VP & $4^{\circ} \mathrm{C}$ & up to $21 \mathrm{~d}$ & $\begin{array}{l}\text { Hot-deboned muscles were tougher than cold-deboned muscles } \\
\text { from } 24 \mathrm{~h} \text { up to five days. }\end{array}$ & $(5)$ \\
\hline Ostrich & VP & $2^{\circ} \mathrm{C}$ & up to $21 \mathrm{~d}$ & $\begin{array}{l}\text { VP had a positive effect on microbiological and sensory } \\
\text { features as compared to non-VP meat. }\end{array}$ & (7) \\
\hline Emu & $\mathrm{VP}$ and $\mathrm{AP}$ & $4^{\circ} \mathrm{C}$ & $9-15 \mathrm{~d}$ & $\begin{array}{l}\text { Microbial counts of emu meat - total plate count and } \\
\text { Enterobacteriaceae counts were higher in AP than in VP. } \\
\text { Microbial load was below } 7-8 \log \text { cfu/g }\end{array}$ & (32) \\
\hline $\begin{array}{l}\text { Rhea ( } 2 \\
\text { muscles) }\end{array}$ & $\mathrm{VP}$ and $\mathrm{AP}$ & $4^{\circ} \mathrm{C}$ & $5-28 d$ & $\begin{array}{l}\text { Ultimate } \mathrm{pH} \text { was similar in both muscles. With storage under } \\
\mathrm{AP} \text {, lipid oxidation of rhea muscles increased up to } 275 \% \text {. }\end{array}$ & (16) \\
\hline
\end{tabular}

VP - vacuum packaging, AP - air packaging, VPS - vacuum skin packaging

Table 2. The effect of modified atmosphere packaging (MAP) on shelf life of ostrich meat

\begin{tabular}{|c|c|c|c|c|c|}
\hline Type of packaging & Gas mix & $\begin{array}{l}\text { Storage } \\
\text { temperature }\end{array}$ & $\begin{array}{l}\text { Storage } \\
\text { time in } \\
\text { days }\end{array}$ & Quality meat evaluation & Reference \\
\hline MAP & $\begin{array}{l}\mathrm{O}_{2} ; \mathrm{CO}_{2} ; \mathrm{N}_{2} \\
-80: 20: 0 \\
-60: 20: 20 \\
-60: 40: 0 \\
-40: 40: 20\end{array}$ & $4^{\circ} \mathrm{C}$ & 10 & $\begin{array}{l}\text { Meat packaged with high } \mathrm{CO}_{2} \\
\text { concentrations had lower mean } \\
\text { TBARS values during the } 10 \\
\text { days of storage as compared to } \\
\text { meat packaged in } \mathrm{O}_{2} \text {. }\end{array}$ & (4) \\
\hline MAP & $\begin{array}{l}\mathrm{CO}_{2}: \mathrm{N}_{2} \\
-80: 20 \%\end{array}$ & & & The presence of $\mathrm{CO}_{2}$ extends & \\
\hline $\mathrm{MAP}+\mathrm{CO}$ & $\begin{array}{l}\mathrm{CO}_{2}: \mathrm{Ar}: \mathrm{CO} \\
-30: 69.8: 0.2\end{array}$ & $4^{\circ} \mathrm{C}$ & 12 & $\begin{array}{l}\text { the shelf life of ostrich steaks by } \\
\text { stabilisation of red colour and } \\
\text { sensory techniques, and } \\
\text { maintenance of fresh meat } \\
\text { odour. }\end{array}$ & $(15)$ \\
\hline OMAP & $\begin{array}{l}\mathrm{CO}_{2} / \mathrm{O}_{2} \\
-30: 70\end{array}$ & & & $\begin{array}{l}\text { MAP enhances the shelf life of } \\
\text { fresh meat and could be applied }\end{array}$ & \\
\hline NMAP & $\begin{array}{l}\mathrm{CO}_{2} / \mathrm{N}_{2} \\
-30: 70\end{array}$ & $4^{\circ} \mathrm{C}$ & 10 & $\begin{array}{l}\text { in the industry and the overwrap } \\
\text { packaging was found not } \\
\text { suitable for meat packaging due } \\
\text { to the rapid oxidation of } \\
\text { myoglobin and great loss of } \\
\text { moisture }\end{array}$ & $(28)$ \\
\hline
\end{tabular}

At the end of storage duration, the percentage of metmyoglobin and the levels of lipid oxidation (TBARS) were more than two-fold higher in the $M$. iliofiburalis than in the $M$. gastrocnemius. Ultimately, long-term frozen storage only slightly affected the overall quality of rhea meat. Nutritional value and digestion rate of rhea meat proteins in association with storage and cooking processes were also investigated by this research group (18). Storage influenced Schiff bases formation indicating the presence of protein-aldehyde adducts after cooking. High content of Schiff bases was found after cooking of samples stored for five days. The study showed that storage time had less impact on protein changes in rhea 
meat than cooking. The formation of Schiff bases and aggregates seemed to be the result of both hydrophobic and covalent interactions of proteins and lipid oxidation products. Moreover, a combined effect of storage under air and heating on protein aggregation was reported (18).

\section{Modified atmosphere packaging (MAP)}

It should be noted that a very limited research was conducted in relation to the influence of modified atmosphere packaging (MAP) on shelf life quality of ratite meat, including its technological and nutritional properties. There are only a few papers including ostrich meat (Table 2). Fernandez-Lopez et al. (15) assessed the shelf life of ostrich steaks stored in four different packaging types: air exposure, vacuum, and two different types of MAP: $80 \% \mathrm{CO}_{2}+20 \% \mathrm{~N}_{2}$, and MAP + CO: $30 \% \mathrm{CO}_{2}+69.8 \%$ argon $+0.2 \% \mathrm{CO}$. They observed that the sharpest decline in $\mathrm{pH}$ and related decrease in lactic acid bacteria count were in the VP samples, and AP meat showed a significantly higher aerobic bacteria count when compared to VP. Based on aerobic bacteria counts, the shelf life of ostrich steaks stored under AP would be 8 days at most, whereas under vacuum, MAP or MAP + CO it would amount to 12 days. The presence of $\mathrm{CO}$ extends the shelf life of ostrich steaks by stabilisation of red colour and sensory techniques, and maintenance of fresh meat aroma. Interesting results were obtained by Sakowska et al. (44) for beef where the authors investigated the impact of $0.5 \%$ carbon monoxide in MAP on selected quality parameters of beef muscles. The authors showed that the use of $0.5 \% \mathrm{CO}$ as a component in the gas mixture in MAP enabled to maintain the preferred red colour of beef under anaerobic conditions for 21 days. Bingol et al. (4) studied the effects of various concentrations of $\mathrm{O}_{2} / \mathrm{C}_{2}$ in MAP on the shelf life quality of ostrich meat. They packaged ostrich meat under five various gas mixtures: air and $\mathrm{O}_{2} ; \mathrm{CO}_{2} ; \mathrm{N}_{2}$ ratios of 80:20:0, 60:20:20, 60:40:0, and 40:40:20 at $4^{\circ} \mathrm{C}$ for 10 days (Table 2). As a result, the meat quality and shelf life of ostrich meat under various gas compositions were improved. For example, the high $\mathrm{CO}_{2}$ content (40\%) prevented increased lipid oxidation and increased acceptable shelf life. Ostrich meat packaged with high $\mathrm{CO}_{2}$ concentrations had lower mean TBARS values during the 10 days of storage compared to meat in $\mathrm{O}_{2}$ packages. The longer the exposure to high $\mathrm{CO}_{2}$ concentration, the more effective the inhibition of microbial growth and shelf life were. They increased by 5-7 days. Although high concentrations of $\mathrm{CO}_{2}$ may be beneficial for inhibiting microorganism growth, high $\mathrm{CO}_{2}$ level in MAP is often the cause of darkening in meat products due to the formation of metmyoglobin. According to Martinez et al. (30) in order to reach higher colour retention and freshness, it is advisable to use low $\mathrm{CO}_{2}$ concentrations $(20 \%)$, rather than high ones $(60 \%)$. In turn, high $\mathrm{O}_{2}(80 \%)$ concentration led to higher lipid oxidation and to the development of undesirable flavours, and did not extend the shelf life of ostrich meats compared to air-packaged ones. According to Veberg et al. (47), pork meat is more stable against lipid oxidation and no development of fluorescent lipid oxidation products was detected when stored at $4^{\circ} \mathrm{C}$ under high-oxygen $\left(\mathrm{O}_{2}\right)$ MAP and vacuum. However, TBARS values of pork meat $\left(4^{\circ} \mathrm{C}\right)$ increase with the increase in $\mathrm{O}_{2}$ concentration inside the package. MAP of $55 \% \mathrm{O}_{2}$ or more is necessary for maintaining a good colour of beef loins. On the other hand, according to Jakobsen et al. (21), oxygen levels have a smaller effect on lipid oxidation compared to temperature during storage.

Leygonie et al. (28) in the study on quality of packaged ostrich meat under different MAP packaging conditions: $30: 70, \mathrm{CO}_{2} / \mathrm{O}_{2}$ (OMAP), $30: 70 \quad \mathrm{CO}_{2} / \mathrm{N}_{2}$ (NMAP) compared to traditional air packaging method, and stored at $4{ }^{\circ} \mathrm{C}$ for 10 days showed that $\mathrm{pH}$ was constant in the MAP groups, whereas it increased in air packaging conditions. The same tendency occurred for drip loss. In turn, TBARS remained constant for NMAP (2,4 MDA/kg meat and 3.1 for air packaging), whereas increased significantly for OMAP - $10 \mathrm{mg} \mathrm{MDA} / \mathrm{kg}$ of meat. The colour stability was greatly enhanced in OMAP. The authors concluded that MAP enhances the shelf life of fresh ostrich meat and could be applied in the industry, whereas the overwrap packaging was found not suitable for ostrich meat packaging due to the rapid oxidation of myoglobin and great loss of moisture, diminishing the shelf life. According to Camo et al. (8), rapid oxidation can be decreased using active packaging systems $\left(80 \% \mathrm{O}_{2} / 20 \% \mathrm{CO}_{2}\right)$ containing oregano extract, which was evaluated with reference to beef steaks.

Based on the delivered data we can assume that generally the shelf life of ratite meat is similar to that in poultry meat $(3,19)$, but shorter in comparison to other popular red meats like beef, pork, lamb $(8,9)$, and can be associated with the high ultimate $\mathrm{pH}$, initial microbioal loads (2), and relatively high amounts of PUFA and haeme-iron in ratite meat.

\section{Conclusions}

This article provides updated information regarding the type of packaging of ratite meat currently in use on the market. These data may be useful for both consumers and the industry, since appropriate method of packaging affects the shelf life quality of this healthy, exotic meat. However, the knowledge about this issue is still limited, compared to available data on traditional meats like beef, pork, and chicken. Thus, it can be concluded that since the emu ratite meat is relatively new and unfamiliar to processors and consumers, it is important that the meat is extensively tested to determine proper aging duration and suitable packaging requirements to encourage greater consumption and production. More complete and comprehensive studies on the 
microbiological quality of rhea meat during storage and the use of modified atmosphere packaging are necessary. For better distribution and promotion of ostrich, emu, and rhea meat, further studies on improvement and optimisation of the storage packaging conditions of these meats should be carried out. Moreover, there is a need for research aiming at extending the shelf life of ratite meat (taking into account its high susceptibility to oxidation processes), including development of an innovative, alternative packaging system for better preservation of nutritional and technological properties.

Conflict of Interests Statement: The authors declare that there is no conflict of interests regarding the publication of this article.

Financial Disclosure Statement: This article was financed by the University of Life Sciences in Warsaw, Faculty of Human Nutrition and Consumer Sciences.

Animal Rights Statement: None required.

\section{References}

1. Arvanitoyannis I., Stratakos A.C.: Application of modified atmosphere packaging and active/smart technologies to red meat and poultry: a review. Food Bioprocess Technol 2012, 5, 1423-1446.

2. Alonso-Calleja C., Martinez-Fernandez B., Prieto M., Capita R.: Microbiological quality of vacuum-packed retail ostrich meat in Spain. Food Microbiol 2004, 21, 241-246.

3. Balamatsia C.C., Patsias A., Kontominas M.G., Savvaidis I.N.: Possible role of volatile amines as quality-indicating metabolites in modified atmosphere-packaged chicken fillets: correlation with microbiological and sensory attributes. Food Chem 2007, 104, 1622-1628.

4. Bingol E.B., Ergun O.: Effect of modified atmosphere packaging (MAP) on the microbiological quality and shelf life of ostrich meat. Meat Sci 2011, 88, 774-785

5. Botha S.St.C., Hoffman L.C., Britz T.J.: Physical meat quality characteristics of hot-deboned ostrich (Struthio camelus var. Domesticus) muscularis gastrocnemius, pars interna during postmortem aging. Meat Sci 2007, 75, 709-718.

6. Bolumar T., Andersen M.L., Orlien V.: Antioxidant active packaging for chicken meat processed by high pressure treatment. Food Chem 2011, 129, 4, 1406-1412.

7. Brenesselova M., Korenekova B., Macanga J., Marcincak S., Jevinova P.: Effect of vacuum packaging conditions on the quality, biochemical changes and the durability of ostrich meat. Meat Sci 2015 101, 42-47.

8. Camo J., Lorés A., Djenane D., Beltrán J.Á., Roncalés P.: Display life of beef packaged with an antioxidant active film as a function of the concentration of oregano extract. Meat Sci 2011, 88, 174-178.

9. Capita R., Diaz-Rodriguez N., Prieto M., Alonso-Callrja C.: Effects of temperature, oxygen exclusion, and storage on the microbial loads and $\mathrm{pH}$ of packed ostrich steaks. Meat Sci 2006, 73, 498-502.

10. Charuta A., Tatara M., Krupski W., Poławska E., Ogłuszka M., Pierzchała M., Łuszczewska-Sierakowska I.: Bone morphometric. densitometric and mechanical properties in 14-month-old ostriches fed experimental diet enriched with linseed. Anim Sci Pap Rep 2015, 33, 383-398.

11. Chouliara E., Karatapanis A., Savvaidis I.N., Kontominas M.G.: Combined effect of oregano essential oil and modified atmosphere packaging on shelf-life extension of fresh chicken breast meat, stored at $4^{\circ} \mathrm{C}$. Meat Sci 2007, 24, 607-617.

12. Cooper R.G., Naranowicz H., Maliszewska E., Tennett A., Horbańczuk J.O.: Sex-based comparison of limb segmentation in ostriches aged 14 months with and without tibiotarsal rotation. J S Afr Vet Assoc 2008, 79, 142-144.

13. Cooper R.G., Tomasik C., Horbańczuk J.O.: Avian influenza in ostriches (Struthio camelus). Avian Poult Biol Rev 2007, 18, 87-92.

14. Esteves M., Ventanas S., Cava R.: Protein oxidation in frankfurters with increasing levels of added rosemary essential oil: effect on color and texture deterioration. J Food Sci 2005, 70, 427-432.

15. Fernandez-Lopez J., Jimenez S., Sayas-Barbera E., Sendra E., Perez-Alvarez J.A.: Quality characteristics of ostrich (Struthio camelus) burgers. Meat Sci 2006, 73, 295-303.

16. Filgueras R.S., Gatellier P., Aubry L., Thomas A., Bauchard D., Durand D., Zambiazi R.C., Sante-Lhoutellier V.: Colour, lipid and protein stability of Rhea americana meat during air-and vacuumpacked storage: influence of muscle on oxidative processes. Meat Sci 2010, 86, 665-673.

17. Filgueras R.S., Gatellier P., Zambiazi R.C., Sante-Lhoutellier V.: Effect of frozen storage duration and cooking on physical and oxidative changes in $M$. gastrocnemius pars interna and M. iliofiburalis rhea americana. Meat Sci 2011, 88, 645-651.

18. Filgueras R.S., Gatellier P., Ferreira C., Zambiazi R.C., SanteLhoutellier V.: Nutritional value and digestion rate of rhea meat proteins in association with storage and cooking processes. Meat Sci 2011, 89, 6-12

19. Gonzalez-Montalvo B., Capita R., Guevara-Franco J.A., Prieto M., Alonso-Calleja C.: Influence of oxygen exclusion and temperature on pathogenic bacteria levels and sensory characteristics of packed ostrich steaks throughout refrigerated storage. Meat Sci 2007, 76, 201-209.

20. Horbańczuk O.K., Wierzbicka A.: Technological and nutritional properties of ostrich, emu, and rhea meat quality. J Vet Res 2016, 60, 279-286.

21. Jakobsen M., Bertelsen G.: The use of $\mathrm{CO}_{2}$ in packaging of fresh red meats and its effect on chemical quality changes in the meat: a review. J Muscle Foods 2002, 13, 143-168.

22. Kawka M., Horbańczuk J.O., Sacharczuk M., Zięba G., Łukaszewicz M., Jaszczak K., Parada R.: Genetic characteristics of the ostrich population using molecular methods. Poult Sci 2007 , 86, 277-281.

23. Kawka M., Parada R., Jaszczak K., Horbańczuk J.O.: The use of microsatellite polymorphism in genetic mapping of the ostrich (Struthio camelus). Mol Biol Rep 2012, 39, 3369-3374.

24. Kawka M., Horbańczuk J.O., Jaszczak K., Pierzchała M., Cooper R.G.: A search for genetic markers associated with egg production in the ostrich (Struthio camelus). Mol Biol Rep 2012, 39, 7881-7885.

25. Keokamnerd T., Acton J.C., Han I.Y., Dawson P.L.: Effect of commercial rosemary oleoresin preparations on ground chicken thigh meat quality packaged in a high-oxygen atmosphere. Poult Sci 2008, 87, 170-179.

26. Koréneková B., Nagy J., Smulders F.J.M., Paulsen P., Mačanga J., Popelka P., Marcinčák S., Korének M.: Lactic acid concentration and $\mathrm{pH}$ values in muscles of European brown hare. In: Trends in game meat hygiene, from forest to fork. Edited by Paulsen P., Bauer A., Smulders F.J.M. The Netherlands, Wageningen Academic Publishers 2014

27. Lagerstedt Å., Ahnström M.L., Lundström K.: Vacuum skin pack of beef-a consumer friendly alternative. Meat Sci 2011, 88, 391-396.

28. Leygonie C., Britz T.J., Hoffman L.C.: Meat quality comparison between fresh and frozen/thawed ostrich M. iliofibularis. Meat Sci 2012, 91, 364-368

29. Łopacka J., Półtorak A., Wierzbicka A.: Effect of MAP, vacuum skin-pack, and combined packaging methods on physicochemical properties of beef steaks stored up to 12 days. Meat Sci 2016, 119 , $147-153$. 
30. Martinez L., Djenane D., Cilla I., Beltran J.A., Roncales P.: Effect of different concentrations of carbon dioxide and low concentration of carbon monoxide on the shelf-life of fresh pork sausages packaged in modified atmosphere. Meat Sci 2005, 71, 563-570.

31. Naveena B.M., Kiran M.: Emu meat: new source of healthier meat towards niche market. Food Rev Int 2014, 30, 22-35.

32. Naveena B.M., Muthukumar P.S., Kulkarni V.V., Praveen Kumar Y., Usha Rani K., Kiran M.: Effect of aging on the physicochemical, textural, microbial, and proteome changes in emu (Dromaius novaehollandiae) meat under different packaging conditions. J Food Process Pres 2015, 39, 2497-2506.

33. Ntzimani A.G., Paleologos E.K., Savvaidis I.N., Kontominas M.G.: Formation of biogenic amines and relation to microbial flora and sensory changes in smoked turkey breast fillets stored under various packaging conditions at $4^{\circ} \mathrm{C}$. Food Microbiol 2008, 25, 509-517.

34. Otremba M.M., Dikemanb M.E., Boyle E.A.E.: Refrigerated shelf life of vacuum-packaged, previously frozen ostrich meat. Meat Sci 1999, 52, 279-283.

35. Poławska E., Marchewka J., Cooper R.G., Sartowska K., Pomianowski J., Jóźwik A., Strzałkowska N., Horbańczuk J.O.: The ostrich meat - an updated review. II. Nutritive value. Anim Sci Pap Rep 2011, 29, 89-97.

36. Poławska E., Horbańczuk J.O., Pierzchała M., Strzałkowska N., Jóźwik A., Wójcik A., Pomianowski J., Gutkowska K., Wierzbicka A., Hoffman L.C.: Effect of dietary linseed and rapeseed supplementation on the fatty acid profiles in the ostrich. Part 1. Muscles. Anim Sci Pap Rep 2013, 31, 239-248.

37. Poławska E., Półtorak A., Wyrwisz J., Wierzbicka A., Gutkowska K., Pomianowski J., Zdanowska-Sąsiadek Ż., Wójcik A., Kawka M., Raes K., De Smet S.: The physical traits and fatty acids profile of ostrich meat enriched in $\mathrm{n} 3$ fatty acids as influenced by duration of refrigerated storage and type of packaging. Anim Sci Pap Rep 2014, 32, 351-358

38. Poławska E., Tolik D., Horbańczuk O.K., Ciepłoch A., Raes K., De Smet S.: The effect of dietary oil seeds on the fatty acid profile and metabolism in ostrich liver. Anim Sci Pap Rep 2016, 34, 173-180.

39. Poławska E., Zdanowska-Sąsiadek Ż., Horbańczuk J.O., Pomianowski J., Jóźwik A., Tolik D., Ras K., De Smet S.: Effect of dietary organic and inorganic selenium supplementation on chemical, mineral, and fatty acid composition of ostrich meat. CyTa J Food 2016, 14, 84-87.

40. Richards M.P., Modra A.M., Li R.: Role of deoxyhemoglobin in lipid oxidation of washed cod muscle mediated by trout, poultry and beef hemoglobins. Meat Sci 2002, 62, 157-163.

41. Sales J., Horbańczuk J.O.: Ratite Meat. World Poult Sci J 1998, 54, 59-67.

42. Sales J., Horbańczuk J.O., Dingle J., Coleman R., Sensik S.: Carcass characteristics of emus (Dromaius novaehollandiae). Brit Poult Sci 1999, 40, 145-147.

43. Sante-Lhoutellier V., Astruc T., Marinova P., Greve E., Gatellier P.: Effect of meat cooking on physicochemical state and in vitro digestibility of myofibrillar proteins. J Agr Food Chem 2008, 56, 1488-1494.

44. Sakowska A., Guzek D., Sun D.W. Wierzbicka A.: Effects of $0.5 \%$ carbon monoxide in modified atmosphere packaging on selected quality attributes of $M$. Longissimus dorsi beef steaks. J Food Process Eng 2016, doi:10.1111/jfpe.12517.

45. Seydim A.C., Acton J.C., Hall M.A., Dawson P.L.: Effects of packaging atmospheres on shelf-life quality of ground ostrich meat. Meat Sci 2006, 73, 503-510.

46. Vázquez B.I., Carriera L., Franco C., Fente C., Cepeda A., BarrosVelázquez J.: Shelf life extension of beef retailcuts subjected to an advanced vacuum skin packaging system. Eur Food Res Technol 2004, 218, 118-122.

47. Veberg A., Sorheim O., Moan J., Iani V., Juzenas P., Nilsen A.N., Wold J.P.: Measurement of lipid oxidation and porphyrins in high oxygen modified atmosphere and vacuum-packed minced turkey and pork meat by fluorescence spectra and images. Meat Sci 2006, $73,511-520$. 